\title{
Development of a beverage based on citric juice with the addition of whey
}

\section{Desenvolvimento de uma bebida à base de suco cítrico com adição de soro de leite}

\author{
Roy Criatian Rivero ${ }^{1,2 *}$, Constanza Morel ${ }^{1}$ (D), Natalia Sosa ${ }^{1,2}$ (i) \\ ${ }^{1}$ Universidad Nacional de Entre Ríos, Facultad de Bromatología, Gualeguaychú/Entre Ríos, Argentina \\ ${ }^{2}$ Consejo Nacional de Investigaciones Científicas y Técnicas - CONICET, Buenos Aires, Argentina
}

*Corresponding Author: Roy Criatian Rivero. Universidad Nacional de Entre Ríos, Facultad de Bromatología.

Perón 64 (2820), Gualeguaychú, Entre Ríos. e-mail: rrivero@fb.uner.edu.ar

Cite as: Rivero, R. C., Morel, C., \& Sosa, N. (2020). Development of a beverage based on citric juice with the addition of whey. Brazilian Journal of Food Technology, 23, e2018191. https://doi.org/10.1590/1981-6723.19118

\begin{abstract}
Faced with new trends in healthy eating, there is a need to expand this market. The Argentine Society of Nutrition, based on local and international studies, has suggested that an adequate intake of dairy products not only provides calcium but also provides compounds associated with a decrease in the risk of chronic inflammatory diseases. The objectives of this work were to formulate and develop beverages based on orange juice with the addition of liquid and powdered whey, sweetened naturally, and study the physicochemical, nutritional and sensory characteristics. The samples were homogenized and pasteurized at $85^{\circ} \mathrm{C}$ for 30 minutes and the pH value, acidity, solids content and colour were analyzed. A just-about-right (JAR) scale was used to evaluate the intensities of the acid taste, bitter taste and flavour, and also the colour attributes, and a 5-point hedonic scale was used to evaluate the global acceptability of the samples. The intensity analyses showed that the taste and colour were "ideal". With respect to global acceptability, the pleasant categories scored more than $60 \%$ and only $10 \%$ considered it unpleasant. The beverage presented a pH value, colour and solids content similar to those of other citrus beverages, and was rated as pleasant by the consumers.
\end{abstract}

Keywords: Calcium; Whey; Citrus drink; Sensory evaluation.

\section{RESUMO}

Considerando as novas tendências para alimentação saudável, há uma necessidade de expandir este mercado. A Sociedade de Nutrição da Argentina, baseada em estudos locais e internacionais, tem sugerido que um consumo adequado de laticínios não apenas fornece o cálcio, mas também fornece compostos associados com a diminuição do risco de doenças inflamatórias crônicas. Os objetivos deste trabalho foram formular e desenvolver bebidas baseadas em suco de laranja com adição de soro de leite na forma líquida ou em pó, adoçadas de uma forma natural, e estudar as características físico-químicas, nutricionais e sensoriais. As amostras foram homogeneizadas e pasteurizadas a $85{ }^{\circ} \mathrm{C}$ por 30 minutos, e os valores de $\mathrm{pH}$, acidez, conteúdo de sólidos e cor foram analisados. A escala quase certa (JAR) foi usada para avaliar as intensidades dos gostos ácidos e amargos, o sabor e os atributos de cor, sendo que uma escala hedônica de cinco pontos foi usada para avaliar a aceitabilidade global das amostras. As análises de intensidade mostraram que os gostos e a cor foram "ideais". Com respeito à aceitabilidade global, as 
categorias de agradável foram apontadas com mais de $60 \%$ e apenas $10 \%$ consideraram a bebida desagradável. A bebida apresentou valores de $\mathrm{pH}$, cor e conteúdo de sólidos semelhantes aos de outras bebidas cítricas, e foi avaliada como agradável pelos consumidores.

Palavras-chave: Cálcio; Soro de leite; Bebida cítrica; Avaliação sensorial.

\section{Introduction}

The population is currently more aware about following a healthy lifestyle to prevent health problems and the risks of suffering from Chronic Noncommunicable Diseases (CNCD) associated with sedentary habits and bad nutrition (Hossain, 2017).

The current nutritional transition is characterized by a modification of the feeding patterns, modifications of the average nutritional needs of the population, a decrease in the manifestation of malnutrition and an increase in the prevalence of CNCD and deficiencies of specific nutrients (Torresani \& Somoza, 2009). The National Survey of Nutrition and Health (Encuesta Nacional de Nutrición y Salud, 2005) mentions the existence of nutritional inadequacy situations in children, in women from 10 to 49 years of age and in pregnant women.

One of the most relevant results is the risk of a deficient calcium intake. Calcium is the mineral found in the greatest proportion in the human body. It occurs in $90 \%$ of the body forming part of the bones and teeth. Its properties are related to growth and development, in helping strengthen the bones and teeth, in blood clotting, nerve signals, and in muscle relaxation and contraction (Narváez Andino \& Reyes Toval, 2013).

The estimated average requirement (EAR) for calcium is $1000 \mathrm{mg} /$ day for adults from 19 to 50 years of age. Women from 51 to 70 years of age are considered separately from men, with a requirement for $1200 \mathrm{mg} /$ day (González Sánchez et al., 2012). It has been shown that the calcium consumption in Latin America is below the requirements for most age groups (Cerezo de Ríos et al., 2014).

According to a population study of 4328 subjects of both sexes between 18 and 80 years carried out in Córdoba, Argentina, the calcium intake of half of the individuals provided by food did not exceed a daily intake of $734 \mathrm{mg}$ of calcium, and the female subjects showed a smaller amount of this mineral as compared to the male subjects, independent of their nutritional status (Aballay, 2012).

Low calcium consumption can cause diseases such as osteoporosis and a high incidence of fractures, especially in postmenopausal women (Zamudio et al., 2015). The beginning of bone loss is associated with changes in the calcium metabolism during this stage (Fischer et al., 2018).

Considering previous studies, for all age groups, the female population presented the lowest mineral consumption. Thus the focus of this work was on the female population, specifically women aged between 35 and 65 years, a stage during which the events of the climacteric and menopause occur (Capote Bueno et al., 2011).

A study called 'Hidratar I' showed that the average liquid consumption by the Argentine population was $2050 \mathrm{ml} /$ day, and the study allowed for a definition of the 'Liquid Pitcher' that the Argentines ingest, showing that half of the volume corresponds to flavoured beverages and sugary infusions, $29 \%$ to flavoured beverages and infusions without sugar and $21 \%$ to pure water (Carmuega et al., 2015). The average amount of sugar contributed by the sugary beverages and infusions determined that the amount of sugar ingested from liquids already reached or exceeded the limit of intake of free sugars recommended by WHO $(10 \%$ of the calories) (Fagúndez, 2017). Thus item $\mathrm{n}^{\circ} 5$ of the new dietary guidelines for the Argentine population (2016) proposed a limit on the consumption of sugary beverages (Ministry of Health of Argentine, 2016).

The Galician Food Cluster 2017 (Clusaga) dedicated a whole day to the analysis of global trends in the dairy sector as detected during the previous year, and noted that consumers had been attracted to milk-derived 
beverages with good nutritional and sensory properties. Thus the principal technological challenge in the development of this type of product is to mask the organoleptic characteristics of the milk and highlight the fruit flavors in milk-derived beverages with good nutritional and sensory properties (Walsh et al., 2017).

Considering the above, the purpose of this work was to develop a calcium drink based on orange juice with the addition of whey (liquid and freeze-dried), naturally sweetened with stevia and honey and destined for adult women aged between 35 and 65 from the city of Gualeguaychú; carrying out a sensory evaluation, nutritional analysis and determination of the physicochemical characteristics. The beverage should provide significant amounts of calcium per portion, and according to the regulatory requirements, when $7.5 \%$ of the IDR or DDR is provided by a single portion $(100 \mathrm{~mL})$ the beverage can be declared as a "source of the mineral" (Administración Nacional de Medicamentos, Alimentos y Tecnología Médica, 2017). The present study aimed to provide nutritional alternatives that complemented the calcium diet and therefore improved the consumption profile, mainly in the female population between 35 and 65 years old, without generating an excessive caloric intake when compared with similar commercial products.

\section{Materials and methods}

In the development of the formulations (F), juice from the Navel $s p$ variety of oranges (Concordia Entre Ríos, The Argentine) was used as the main ingredient. The whey, kindly supplied by Cotagú (Gualeguaychú, Entre Ríos, The Argentine), was refrigerated until used. The chemical composition of the whey in percentage was: proteins 1.2; fat 0.35; carbohydrates 4.8; ash 0.95; and water 92.7. SanCor ${ }^{\circledR}$ Gala honey (Córdoba, The Argentine) and Dulsevia ${ }^{\circledR}$ stevia powder (Posadas, Misiones, The Argentine) were used as sweeteners.

\subsection{Development of the formulations}

\subsubsection{Orange juice with liquid whey}

The oranges were first manually washed to remove impurities, then squeezed and the juice passed through a stainless steel sieve to eliminate pulp and seeds. The formulations were then prepared using different amounts of juice, liquid whey, honey and stevia.

Finally, all the ingredients were mixed, homogenized and poured into covered glass containers for pasteurization at $85^{\circ} \mathrm{C}$ for 30 minutes in a thermostatic bath (Stumbo, 1973). The pasteurization temperature ensured the destruction of bacteria, moulds and yeasts, and the time of 30 minutes was necessary to reach the thermal center of the container. Once the thermal process was finished, the formulations were cooled to room temperature and refrigerated at $4{ }^{\circ} \mathrm{C}$ for storage. Table 1 shows the seven formulations developed.

Table 1. Percent composition of the beverage formulations.

\begin{tabular}{ccccccccc}
\hline Ingredients & F 1 & F 2 & F 3 & F 4 & F 5 & F 6 & F 7 \\
\hline Orange juice & 87.45 & 87.40 & 87.35 & 87.30 & 87.85 & 86.85 & 86.35 \\
\hline Liquid whey & 10.00 & 10.00 & 10.00 & 10.00 & 10.00 & 10.00 & 10.00 \\
\hline Honey & 2.50 & 2.50 & 2.50 & 2.50 & 2.00 & 3.00 & 3.50 \\
\hline Stevia & 0.05 & 0.10 & 0.15 & 0.20 & 0.15 & 0.15 & 0.15 \\
\hline
\end{tabular}

\subsubsection{Orange juice with freeze-dried whey}

Powdered whey was obtained by freezing $\left(-24^{\circ} \mathrm{C}\right)$ individual portions of liquid whey for two days, and then freeze-drying at $-50{ }^{\circ} \mathrm{C}$ and 0.032 mbar for 48 hours (FreeZone, Labconco, Kansas, USA). Finally, individual freeze-dried whey portions were ground to the desired granulometry. 
The orange juice was obtained using a procedure similar to that reported in section 1.1.1. but adding the freeze-dried whey powder, allowing for a greater quantity of components from the whey in the final product. Table 2 shows the four formulations developed.

Table 2. Percent composition of the beverage formulations.

\begin{tabular}{ccccc}
\hline Ingredients & F8 & F9 & F10 & F11 \\
\hline Orange Juice & 83.00 & 86.00 & 88.75 & 87.50 \\
\hline Freeze-dried whey powder & 9.00 & 9.00 & 10.00 & 10.00 \\
\hline Honey & 7.00 & 4.00 & 1.00 & 0.25 \\
\hline Stevia & 1.00 & 2.00 & 0.50 \\
\hline
\end{tabular}

Initially, the authors proposed to prepare formulations providing $200 \mathrm{mg}$ of $\mathrm{Ca}^{2+}$ per serving $(200 \mathrm{~mL})$, but an undesirable precipitate was observed in the orange juice. Therefore the formulations presented in this work are those that incorporated the maximum amount of whey without observing the formation of a precipitate in the final beverage.

\subsection{Sensory evaluation}

\subsubsection{Internal panel}

The sensory evaluation was carried out using an internal panel composed of 30 untrained women panelists; where the experimental design of the product was discussed. The panelists selected presented characteristics similar to those of the target population for the product. This type of evaluation is carried out to investigate the relative acceptability of the products (Watts et al., 1992). The formulations most preferred by the internal panel were used for the sensory evaluation with consumers.

\subsubsection{Consumer panel}

The sensory panel was made up of frequent consumers of orange juice aged between 18 and 64. Seventyfive panelists evaluated the orange juice with liquid whey beverage and ninety-two evaluated the orange juice with powdered whey beverge (Moskowitz et al., 2012). The methods used for the sensory evaluation were those normally used to evaluate products before launching them onto the market (Ibañez \& Barcina, 2001).

Paired Preference test: This refers to the choice of the evaluators between one of two drink samples. To carry out this test, the samples were coded with a random three-digit number and presented to the panelists. The panelists were asked to select the preferred sample, and then proceed to the remaining tests using the preferred sample (American Society for Testing and Materials, 1975).

Just-about-right (JAR): This evaluation was carried out with the formulations selected in the paired preference test, using a scale to measure the adequacy level of a determined attribute in the product (Lawless \& Heymann, 2010). It consisted of asking the consumers to describe the perceived intensity of each attribute using a three-point scale, the intensity being registered as 'very intense', 'just right' or 'not very intense' according to the representation that each person possessed of "'just right" (Bruzzone, 2014).

Evaluation of the degree of satisfaction: this test measures the pleasant or unpleasant sensations produced by the samples on tasting it (Anzaldúa Morales, 1994). The degree of satisfaction of the acid taste, bitter taste, flavour and colour attributes and global satisfaction of the product was studied using 5 and 7-point hedonic scales (Ramírez-Navas, 2012). 


\subsection{Physicochemical characteristics}

The preferred formulations were submitted o a physicochemical characterization using the following determinations.

\subsubsection{Instrumental colour evaluation}

The surface colour was measured using a portable photocolorimeter (Hunter Lab MiniScan EZ, CIUDAD, USA) in the CIELAB colour space, with a D65 illuminant and $2^{\circ}$ observer angle. The parameters $\mathrm{L}^{*}, \mathrm{a}^{*}$ and $\mathrm{b}^{*}$ were registred, where $\mathrm{L}^{*}$ indicated luminosity, $\mathrm{a}^{*}$ chromaticity on an axis going from green $(-)$ to red $(+)$, and $b^{*}$ chromaticity on an axis going from blue $(-)$ to yellow $(+)$.

\subsubsection{Total solids}

The total solids content was determined using the indirect method of the dry weight after drying at $105{ }^{\circ} \mathrm{C}$. The weight of the samples was registered before and after drying in a chamber (Lonomex, MCH, Argentina) to constant weight. The total solids were expressed in percentage ( $\mathrm{g}$ of dry sample / $100 \mathrm{~g}$ of sample (dry basis; d.b.)).

\subsection{3 $\mathrm{pH}$ value}

The $\mathrm{pH}$ value of the formulations was determined using a $\mathrm{pH}$ meter (Hanna HI 2223, Romania, EU), previously calibrated with two buffers at $\mathrm{pH} 4.0$ and pH 7.0 (Biopack®, Buenos Aires, Argentina).

\subsubsection{Calcium content}

The calcium content was determined using a flame photometer (INOMETER CRUDO CAAMAÑO, Buenos Aires, Argentina). Ten $\mathrm{mL}$ of sample were incinerated in a muffle furnace (INEF S.R.L, Buenos Aires, Argentina) at $500{ }^{\circ} \mathrm{C}$ until a white ash was obtained. The ash was then dissolved in $50 \% \mathrm{v} / \mathrm{v}$ hydrochloric acid. Subsequently, the signal emitted was compared with that of a single standard calcium solution of $40 \mathrm{mg} / \mathrm{mL}$ and the results expressed as $\mathrm{mg}$ of calcium.

\subsubsection{Statistical analysis}

The determinations were made in triplicate and the results expressed as the mean \pm standard deviation, and analyzed statistically by the analysis of variance (ANOVA) to determine the significant differences between the samples. The analysis of the means was carried out using the Fisher LSD procedure at $p<0.05$ with the Infostat v.2008 software.

\section{Results}

\subsection{Internal panel}

The formulations with liquid whey chosen by the internal panel were F2 and F7, which differed in the content of sweeteners used, masking the flavour of the whey. These formulations were selected because they presented similar percentages preference of $40.0 \%$ and $46.6 \%$, respectively. In addition, both were characterized by a slight smell of whey and considerable perception of citrus and honey flavours. To the contrary, of the formulations with whey powder, F11 was the only one selected, since the taste of whey was masked without being too sweet, and it was preferred by $\sim 81 \%$ of the internal panel. 


\subsection{Consumer panel}

\subsubsection{Paired preference test}

Figure 1 shows the results obtained in the paired comparison test of orange juice with liquid whey, where the preference of the consumers $(n=61)$ was for Formulation 2 as compared to Formulation 7.

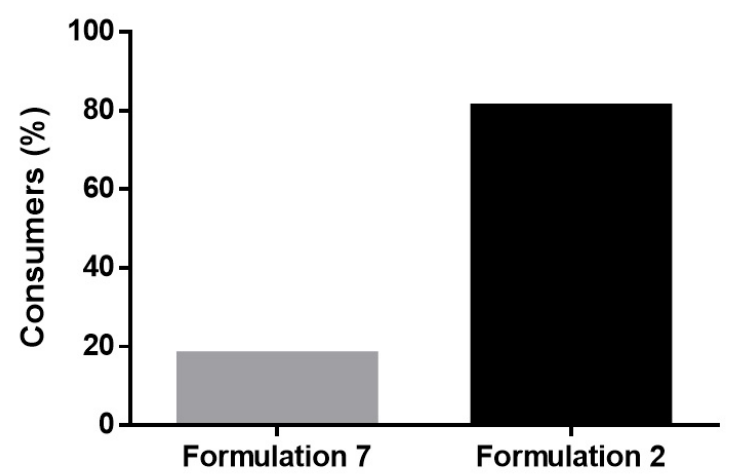

Figure 1. Paired comparison test of the formulations with liquid whey chosen by the internal panel.

\subsubsection{Attribute intensity evaluation}

Figure 2 shows the results obtained for the intensity attribute evaluation of orange juice formulations with liquid whey (F2) and powdered whey (F11).

A

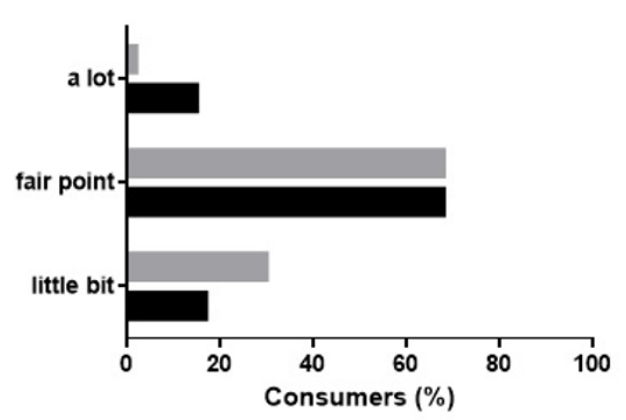

C

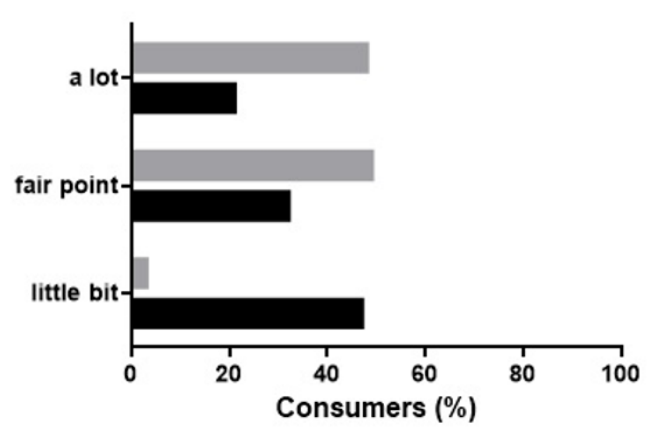

B

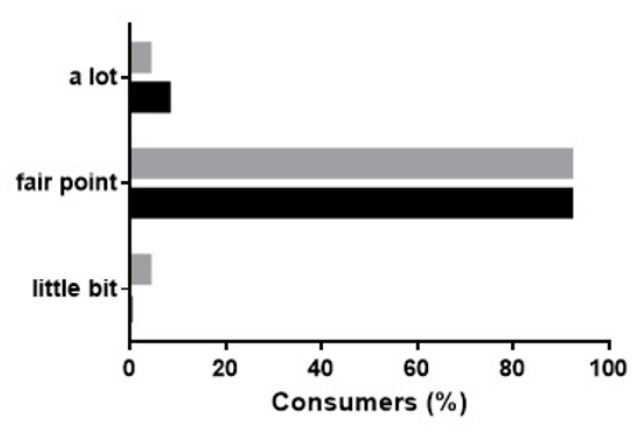

D

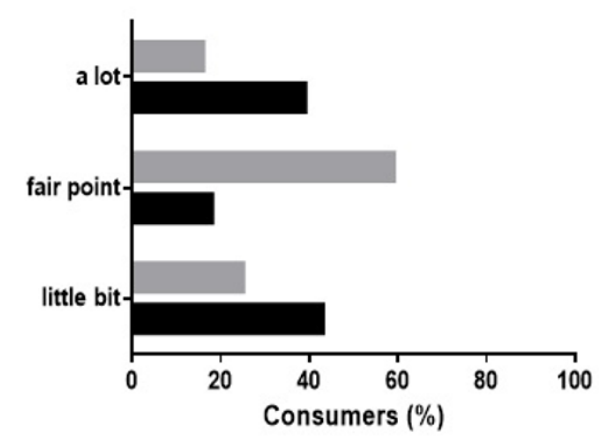

F2 and F11

Figure 2. Intensity levels for the attributes of citrus flavour (A), colour (B), acid taste (C) and bitter taste (D). 
With respect to citrus flavour, both panels considered this attribute to be at the just right point, with $68 \%$ of preference of the total number of evaluators (Figure 2A).

Figure $2 \mathrm{~B}$ shows the results for the colour of the samples, which stands out from the rest of the attributes given that for both formulations, almost all the consumers (92\%) rated it as just right.

On the other hand,Figure $2 \mathrm{C}$ shows that $47 \%$ of the panelists found the beverage F2 not acid enough, while $32 \%$ found it just right. However, for F11, approximately 50\% qualified is as "very acidic and another 50\% as just right.

Figure 2D describes the bitter taste attribute, which was rated as little by $43 \%$ and very high by $39 \%$.

\subsubsection{Evaluation of the degree of satisfaction}

Figure 3 presents the results obtained in the global satisfaction test. It can be seen that F2 presented a value of $63 \%$ for the semantic category of pleasure, $27 \%$ for the category 'I do not like or dislike' and $10 \%$ for the category of 'dislike'. F11 presented $88 \%$ for the semantic category of pleasure, $18 \%$ for the category 'I do not like or dislike' and $8 \%$ for the category of 'dislike'.

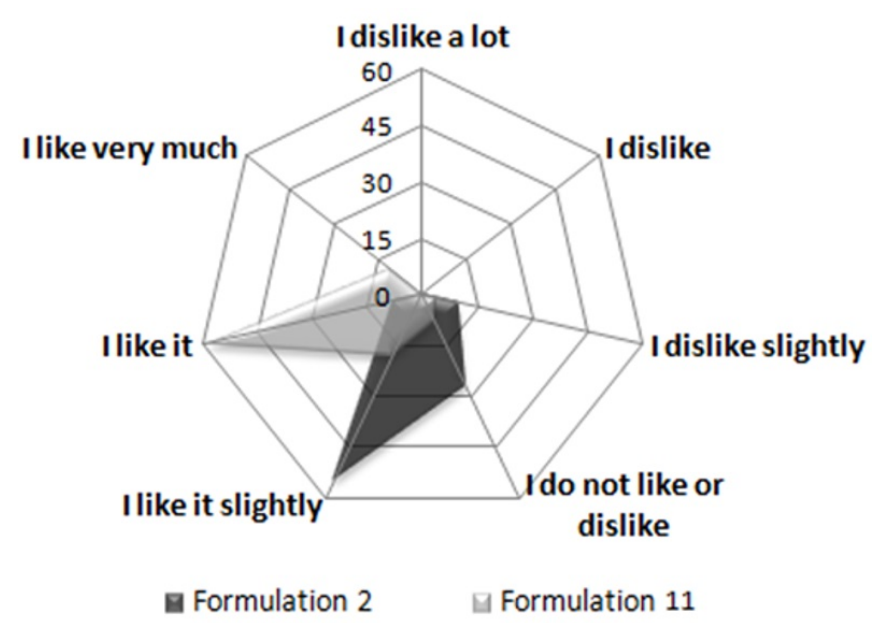

Figure 3. Global acceptance degree for the beverages with whey.

\subsection{Physicochemical properties}

Table 3 shows the results obtained in the physicochemical characterization presenting the average values for $\mathrm{pH}$, total solids, colour and calcium content $(\mathrm{n}=3)$.

Table 3. Physicochemical characterization of the two formulations chosen.

\begin{tabular}{|c|c|c|c|}
\hline \multirow{2}{*}{\multicolumn{2}{|c|}{ Properties }} & Formulation 2 & Formulation 11 \\
\hline & & & \\
\hline \multirow{3}{*}{ Chromatic coordinates } & $\mathbf{X}$ & $10.254 \pm 0.189^{\mathrm{a}}$ & $7.903 \pm 0.200^{\mathrm{b}}$ \\
\hline & $\mathbf{Y}$ & $9.641 \pm 0.068^{\mathrm{a}}$ & $8.008 \pm 0.050^{\mathrm{b}}$ \\
\hline & $\mathbf{Z}$ & $2.847 \pm 0.184^{\mathrm{a}}$ & $3.794 \pm 0.177^{b}$ \\
\hline Total solids g/100mL & & $10.31 \pm 0.20^{\mathrm{a}}$ & $12.65 \pm 0.20^{\mathrm{b}}$ \\
\hline $\mathrm{pH}$ & & $3.8 \pm 0,01^{\mathrm{a}}$ & $4.4 \pm 0.01^{\mathrm{b}}$ \\
\hline Calcium mg/100 mL & & $9.0 \pm 1.0^{\mathrm{a}}$ & $50.0 \pm 1.0^{\mathrm{b}}$ \\
\hline
\end{tabular}


Figure 4 shows the CIE chromaticity diagram used to represent the chromatic coordinates of the samples in order to obtain the dominant wavelength of $580 \mathrm{~nm}$ for F2 and $577 \mathrm{~nm}$ for F11, these wavelengths being associated with the colours "yellow-yellow orange" (Figure 4A) and "yellow" (Figure 4B), respectively.

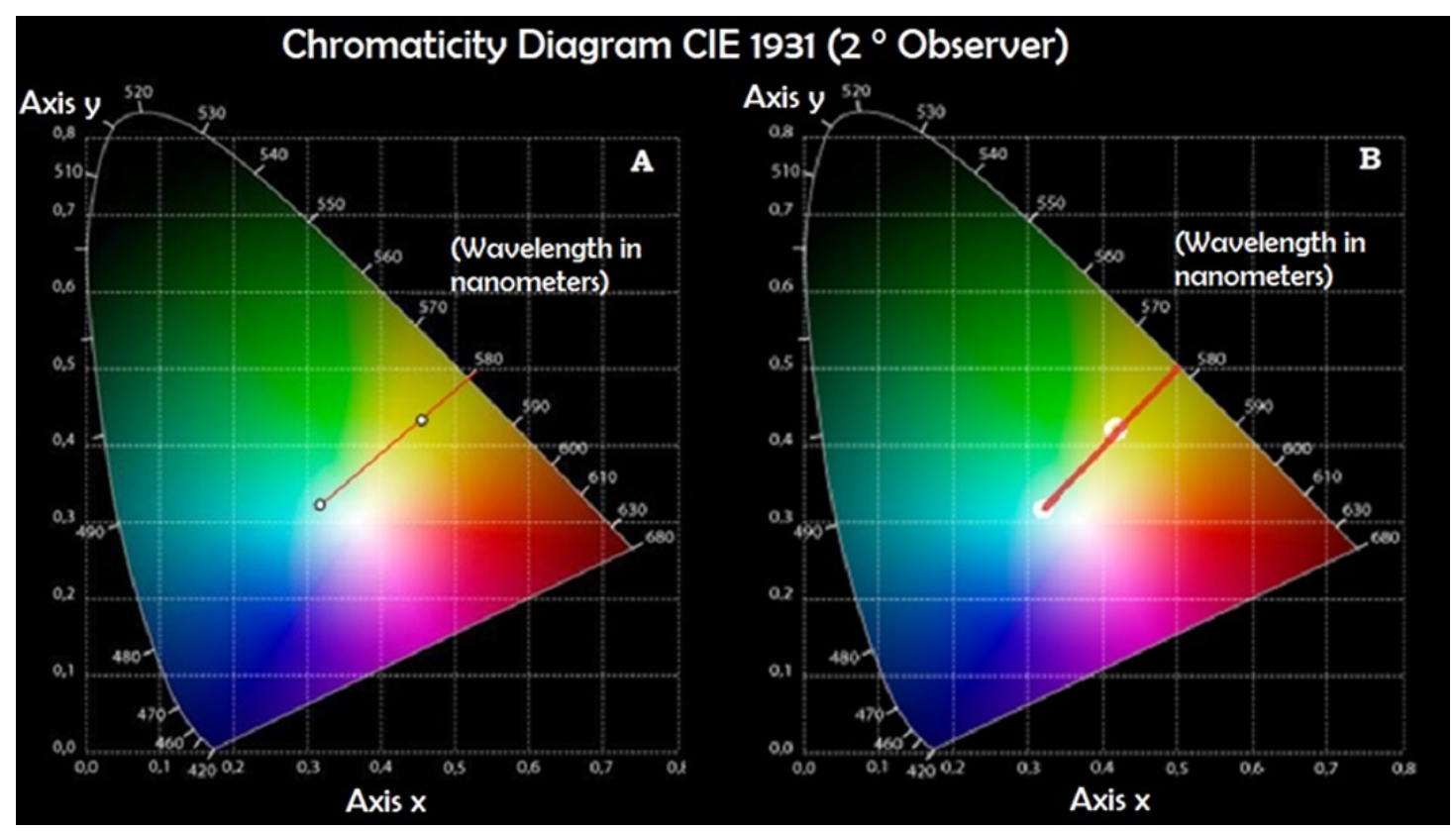

Figure 4. CIE Chromaticities Diagram, F2 (A); F11 (B).

\section{Discussion}

The intensity of the acid attribute was "very acidic" (43\%), indicating the consumers did not like it. Rothman (2007) suggested that when the displeasure category for an attribute was greater than $40 \%$, changes should be made to the formulation of the product to improve its acceptability.

Another attribute that needed to be modified was the bitter taste, that was rated as "little" by $43 \%$ and "very high" by $39 \%$, suggesting the existence of two possible consumer groups for F2, whereas F11 was rated as "just right" by approximately $60 \%$.

Regarding the evaluation of the degree of satisfaction, F11 presented greater acceptability, probably because the incorporation of powdered whey allowed one to increase the fraction of orange juice used, since juice was used to reconstitute the freeze-dried whey powder.

Considering the physicochemical results, the values obtained for the $\mathrm{pH}$ and total solids were similar to those obtained for a beverage based on fermented fresh cheese whey and inoculated with Lactobacillus casei, with values for $\mathrm{pH}$ of 3.73 and of $16.0 \mathrm{~g}$ for total solids (Londoño Uribe et al., 2008). In addition, García-Mogollon et al. (2015) developed a beverage from whey with different concentrations of sugar and passion fruit pulp, where an increase in the sugar concentration and decrease in the $\mathrm{pH}$ were observed, presenting a range from 4.21 to 4.06 . The beverages developed in the present work had a dissolved solids content below $12 \mathrm{~g} / 100 \mathrm{~mL}$ of solution, conforming with the local regulations.

Although both formulations presented a suitable $\mathrm{pH}$ value for this type of product, the beverages were rated as "very acidic" by the consumers.

Regarding the instrumental colour, significant differences were observed in the hue, where F2 presented a yellow orange colour while F11 was orange. However, this variation was not perceived by the consumers.

An increase in the calcium content of the freeze-dried whey drink (F11) was observed, presenting a value of $49.85 \mathrm{mg}$ of calcium / $100 \mathrm{~mL}$ of beverage, and hence a portion $(200 \mathrm{~mL})$ of F11 provides $99.7 \mathrm{mg}$ of 
calcium. According to the CAA, this content is sufficient to provide $66 \%$ of that required to be considered as a source of calcium, which states that it must cover $7.5 \%$ of the Recommended Dietary Allowance (RDA) in $100 \mathrm{~mL}$ of beverage. No more whey was added to reach this calcium value, since the maximum carbohydrate content allowable for the drink was taken into account so as not to exceed the daily calorie limit.

Although a stability study was not carried out, no changes were observed in the product after one month of refrigerated storage $\left(8^{\circ} \mathrm{C}\right)$ protected from the light.

\section{Conclusions}

Two clearly differentiated formulations were physicochemically characterized and submitted to a sensory evaluation. F2 was a drink with a low calcium content and low production cost, that did not require complex processes for its manufacture, and hence would not require a large production input. In contrast, F11 reached $66 \%$ of the calcium required to be considered as a calcium source, but its final cost would be increased by using powdered whey instead of liquid whey.

It must be remarked that the beverages showed a high degree of acceptance by the consumers, who pointed out that the sensory attributes presented ideal characteristics for a citrus drink and and also took advantage of a dairy product normally discarded by the dairy industry.

\section{References}

Aballay, L. R. (2012). La obesidad en Córdoba: estudio de su prevalencia e identificación de factores de riesgo (Doctoral dissertation). Universidad Nacional de Córdoba. Facultad de Ciencias Médicas, Argentina.

Administración Nacional de Medicamentos, Alimentos y Tecnología Médica - ANMAT. (2017). Normas para la rotulación y publicidad de los alimentos. In ANMAT. Resolución GMC No 46/03 - código alimentario argentino (cap. V). Buenos Aires: ANMAT.

American Society for Testing and Materials - ASTM. (1975). Manual on sensory testing and methods (STP 434). Philadelphia: ASTM.

Anzaldúa-Morales, A. A. (1994). Pruebas sensoriales. In A. A. Anzaldúa-Morales. La evaluación sensorial en la teoría y la práctica (pp. 87- 92). Zaragoza: ACRIBIA.

Bruzzone, F. (2014). Aplicación de metodologías de caracterización sensorial con consumidores en el desarrollo de postres lácteos funcionales (Doctoral dissertation). Universidad de la República, Uruguay.

Capote Bueno, M. I., Segredo Pérez, A. M., \& Gómez Zayas, O. (2011). Climaterio y menopausia. Revista Cubana de Medicina General Integral, 27(4), 543-557.

Carmuega, E., Rovirosa, A., \& Zapata, M. (2015). Hidratar: patrones de la ingesta de líquidos de la población argentina.

Cerezo de Ríos, S., Ríos-Castillo, I., Brito O, A., López de Romaña, D., Olivares G, M., \& Pizarro A, F. (2014). Consejería nutricional incrementa el consumo de alimentos ricos en calcio, pero la ingesta se mantiene por debajo del requerimiento diario. Revista Chilena de Nutrición, 41(2), 131-138. http://dx.doi.org/10.4067/S0717-75182014000200002

Encuesta Nacional de Nutrición y Salud - ENNyS. (2005). Alimentos consumidos en Argentina: resultados de la encuesta nacional de nutrición y salud. Ministerio de Salud de la Nación Argentina. http://www.msal.gov.ar/images/stories/bes/graficos/0000000259cnt-a10-alimentos-consumidos-en-argentina.pdf

Fagúndez, G. (2017). Evaluación del consumo de líquidos en pilotos de automovilismo durante los días de competencia (Doctoral dissertation) Universidad de Concepción del Uruguay, Facultad de Ciencias Médicas. Argentina.

Fischer, V., Haffner-Luntzer, M., Amling, M., \& Ignatius, A. (2018, June). Calcium and vitamin D in bone fracture healing and post-traumatic bone turnover. Ecm, 35, pp. 365-385. http://dx.doi.org/10.22203/eCM.v035a25.

García-Mogollon, C., Alvis-Bermudez, A., \& Romero, P. (2015). Aplicación del mapa de preferencia externo en la formulación de una bebida saborizada de lactosuero y pulpa de maracuyá. Información Tecnológica, 26(5), 17-24. http://dx.doi.org/10.4067/S0718-07642015000500004

González Sánchez, M., Rivera Torres, A., \& Morán Fagúndez, L. J. (2012). Estudio nutricional para evaluar el aporte de calcio sobre la dieta de una leche fermentada enriquecida en calcio y vitamina D (Densia ${ }^{\circledR}$ ) en mujeres postmenopáusicas. Nutrición Hospitalaria, 27(2), 537-541. PMid:22732980.

Hossain, M. (2017). A study on behavioral and biological risk factors determination of non-communicable diseases at narayanganj (Doctoral dissertation). East West University, Chicago.

Ibañez, F. C., \& Barcina, Y. (2001). Análisis sensorial de los alimentos: métodos y aplicaciones. Barcelona: Springer-Verlag Ibérica. 
Lawless, H. T., \& Heymann, H. (2010). Acceptance and preference testing. In H. T. Lawless \& H. Heymann. Sensory evaluation of food: principles and practice (pp. 430-479). Springer: New York.

Londoño Uribe, M. M., Sepúlveda Valencia, U. J., Hernández Monzón, A., \& Parra Suescún, E. J. (2008). Bebida fermentada de suero de queso fresco inoculada con Lactobacillus casei. Revista Facultad Nacional de Agronomía, 61(1), 4409-4421.

Ministry of Health of Argentine. (2016). Dietary guidelines for the population of Argentina. Retrieved from: http://www.msal.gob.ar/images/stories/bes/graficos/0000001007cnt-2017-06_guia-alimentaria-poblacion-argentina.pdf Moskowitz, H. R., Beckley, J. H., \& Resurreccion, A. V. (2012). Sensory and consumer research in food product design and development. John Wiley \& Sons. http://dx.doi.org/10.1002/9781119945970.

Narváez Andino, K. J., \& Reyes Toval, Y. C. (2013). Factores que aumentan el riesgo de padecer osteosporosis en pacientes de 60-80 años atendidos en el Centro de Salud Telica, Municipio de Telica-León, marzo-junio del 2013 (Doctoral dissertation). Universidad Nacional Autónoma de Nicaragua, León.

Ramírez-Navas, J. S. (2012). Análisis sensorial: pruebas orientadas al consumidor. Revista ReCiTelA, 12(1), 85-97.

Rothman, L. (2007). The use of just-about-right (JAR) scales in food product development and reformulation. In L. Rothman. Consumer-led food product development (pp. 407-433). Woodhead Publishing.

Stumbo, C. R. (1973). Thermobacteriology in food processing (2nd ed.). New York: Academic Press.

Torresani, M. E., \& Somoza, M. I. (2009). Valoración del estado Nutricional. In M. E. Torresani \& M. I. Somoza. Lineamientos para el cuidado nutricional (pp. 33-42). Buenos Aires: Eudeba.

Walsh, J., Harney, O., \& Hogan, M. (2017) Innovation in personalised nutrition through cluster cooperation in the silver economy. European Commission.

Watts, B., Ylimaki, G., Jeffery, L., \& Elías, L. (1992). Métodos sensoriales básicos para la evaluación semnsorial de alimentos. Otawa: Internacional Development Center.

Zamudio, C., Garmendia, M. L., Corvalán, C., \& Uauy, R. (2015). CO071. Asociación entre obesidad gestacional y complicaciones metabólicas maternas una década después del parto, en mujeres premenopáusicas chilenas. Archivos Latinoamericanos de Nutrición, 65(Suppl. 2), 59. Retrieved in 2018, August 26, from http://www.alanrevista.org/ediciones/2015/suplemento-2/art-59/

Funding: Authors acknowledge the financial support from Universidad de Nacional de Entre Ríos (PIDUNER 9084 Proyect). 